EISSN: 2706-7955 ISSN: 2077-4605

DOI: $10.36632 /$ mejar/2021.10.1.24

Journal homepage: www.curresweb.com

Pages: 383-390

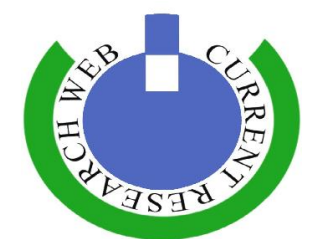

\title{
Effect of Some Amino Acids on Improving the Growth and the Quality of Philodendron selloum
}

\section{Rehab A. Soffar}

Ornamental Plants and Landscape Gardening Research Department, Horticulture Research Institute, ARC, Alexandria, Egypt

Received: 11 January $2021 \quad$ Accepted: 10 March $2021 \quad$ Published: 20 March 2021

\begin{abstract}
Philodendron selloum cv. "Rayo" grown as its ornamental foliage plants were exposed to foliar spray of amino acids Glycine, Tryptophan, and Glutamine at the rates of $(0.0,50,100$, or $150 \mathrm{ppm})$ in the two seasons of 2018 and 2019. All amino acids treatments used in this investigation significantly affected the vegetative growth parameters, and the longevity of cut leaves postharvest. The highest plant height was obtained using glycine (50 or $100 \mathrm{ppm}$ ). Glycine at the level of $50 \mathrm{ppm}$ gave the highest leaves fresh weights in the two seasons of the experiment compared with the control. Glycine foliar spray at $100 \mathrm{ppm}$ gave the highest vase life of cut leaves in the two seasons. Foliar spray with glycine at the level of $(150 \mathrm{ppm})$ gave the highest chlorophyll A, B, carotenoids and total carbohydrates in leaves and stem diameter in the two seasons. The highest number of leaves/plant was significantly affected by glutamine foliar spray at the level of $(100 \mathrm{ppm})$ in both seasons compared with the control plants.
\end{abstract}

Keywords: Philodendron selloum cv. "Rayo", Amino acids, Glycine, Tryptophan, Glutamine, Vase life.

\section{Introduction}

Philodendron genus is delivered from the greek word philo to like and dendron a tree, as was recorded by (Bohming, 1958). Philodendron plants belonged to family Araceae are one of the most remarkable house plants (Abou Dahab and Abdel El-Aziz, 2006). Philodendron is usually grown and is known as an ornamental foliage great plants (Chen et al., 2003). Nowadays the plant known as Philodendron selloum is most accurately called Thaumatophyllum bipinnatifidum. The role of amino acids in plant growth has been explained with several hypothesis. Amino acids as a source of inorganic nitrogenous compounds are essential in protein synthesis, as was reported by (Abd El-Aziz et al., 2010). They noted that amino acids work as buffers that are particularly important in the stimulation of cell growth. Though by containing both acid and basic groups, they remove ammonia from the cell and protect the plant.

Since nitrogen acts as an essential element for plant growth and one of its available forms for plant uptake is nitrate. This last compound is known as a source of nitrate contamination which became an essential human concern (Zahra and Morteza, 2015). Recently, Abd El-Aziz et al., (2009) found that amino acids could be rapidly absorbed by plants more than other inorganic nitrogen compounds. Glycine is an essential metabolite in the chlorophyll synthesis procedure (El-Naggar et al., 2013). Glycine is the extreme widespread amino acid applied in the plant uptake researches. It acts like a nitrogen exporter for the plants in order that its low carbon to nitrogen ratio, low molecular weights and it inhibits the apparent photorespiration done by C3 (Zeiger 2010). Tryptophan also acts as a precursor for auxin synthesis (Gross 1973). Foliar application of amino acid chelating was found to be very useful in preventing leaves from browning, yellowing and abscission (Zahra and Morteza 2015). Tryptophan acts using its indirect role on the growth by influencing auxin synthesis (Abd El-Aziz et al., 2010). While glutamine is the primary product of nitrogen assimilation from inorganic nitrogen sources. It is

Corresponding Author: Rehab A. Soffar, Ornamental Plants and Landscape Gardening Research Department, Horticulture Research Institute, ARC, Alexandria, Egypt.

E-mail: rehabsoffar@gmail.com 
considered a central metabolite in nitrogen metabolism in plants (Chellamuthu et al., 2014). Recently several researchers proved that applying a foliar spray of amino acids enhanced various ornamental plant species vegetative growth and chemical constituents, such as Pelargonium graveolens L. (Talaat, 2005) and Catharanthus roseus L. (Talaat et al., 2005). Furthermore, amino acids cause an increase in bulbs and chlorophyll content in Lilium (El-Nagger et al., 2013). Also, it increased plant growth parameters and either carotenoids and total soluble sugars in leaves of Philodendron erubescens (Abou Dahab and Abd El-Aziz, 2006). A mixture application with amino acids increased floral stem inflorescence and stem diameter in tuberose (Zahra and Morteza, 2015). Foliar applications with amino acids enhanced either plant growth and flowering in many ornamental plant species such as Salvia farinacea plants (Abd El-Aziz and Balbaa, 2007), Syngonium podophyllum (Mazher et al., 2007), and Jasminum grandiflorum (Eid et al., 2009). Additionally, it is reported that foliar sprays of some amino acids, such as lysine, tryptophan and ornithine promoted the vegetative growth and chemical constituents of basil plants (Talaat and Youssef, 2002).

Therefore, the present investigation aimed to study the response of Philodendron selloum cv. "Rayo" to foliar spray applications of glycine, tryptophan, and glutamine and tested their effects on improving growth parameters and the plant cut foliage vase life.

\section{Materials and Methods}

A pot experiment was carried out during the two successive seasons of 2018 and 2019 at Ornamental Plants Research Branch, Antoniades Botanical Gardens in Alexandria, Egypt. The research investigated the effect of amino acids (Glycine, Glutamine, and Tryptophan) at different concentrations $(0.0,50,100$ or $150 \mathrm{ppm})$ to improve the growth, quality and chemical constituents of Philodendron selloum cv. "Rayo".

\subsection{Plant Material}

Plantlets of Philodendron selloum cv. "Rayo" with two leaves/plantlet with an age of three months and an average of $12-14 \mathrm{~cm}$ of height were transplanted in a $20 \mathrm{~cm}$ diameter plastic pot with a mixture of (Peatmoss: Perlite 1:1, v/v) on August 27 $7^{\text {th }}, 2018$ and 2019, in the first and second seasons, respectively. Plantlets were placed in an uncontrolled greenhouse. Each pot was supplied with $2 \mathrm{~g}$. of N.P.K. (19:19:19) fertilizer and added with irrigation tap water in $250 \mathrm{ml} . /$ pot. The fertilizers were added and repeated in six applications at one-month intervals after 21 days from transplanting. Chelated $\mathrm{Zn}, \mathrm{Mn}$, and Fe were added with irrigation tap water at the rate of $0.50 \mathrm{~g}$./pot with irrigation tap water in $250 \mathrm{ml}$./pot as one application after two months from transplanting. Other common cultural practices were performed as needed. The plants were sprayed until run off with amino acids, glycine, tryptophan, and glutamine, each at a concentration of $0.0,50,100$ or $150 \mathrm{ppm}$ applied separately after one month of transplanting and repeated five times at one-month intervals. In addition, control plants were sprayed with tap water. Data were collected after seven months from starting our experiments.

\subsection{Measurements of growth parameters}

\subsubsection{Philodendron vegetative growth:}

- Plant height (cm.).

- Number of leaves.

- Stem diameter (cm.).

- Leaves fresh weight (g.).

- Leaves dry weight (g.).

- Vase life (days): was determined by testing the number of days from cutting Philodendron leaf to the fading stage. The fading stage was set at the point when $50 \%$ of the leaf turned yellow.

\subsection{Chemical Analysis:}

- Chlorophyll A, B and total carotenoids content were determined $\mathrm{mg} / 100 \mathrm{~g}$. fresh weight (mg./100g.f.w.) in the fourth leave according to the method described by (Moran, 1982).

- Total carbohydrate was determined in dry leaves (\%) according to the method described by (Hedge and Hofreider, 1962). 
All chemical analysis was detected in leaves at the end of the experiment.

\subsection{Statistical analysis}

The experimental layout was a randomized complete block design (RCBD). It consists of ten treatments with three replicates; each replicate contains four pots. The data were statistically analyzed according to the method described by (Snedecor and Cochran, 1989). The means of the individual factors were compared by the L.S.D test at a $5 \%$ probability level.

\section{Results and Discussion}

\subsection{Effect of amino acids on Philodendron vegetative growth. \\ 3.1.1. Plant height $(\mathrm{cm})$}

Data presented in table (1) revealed that, spraying plants with amino acids gave a high significant difference and affected the philodendron plant height. The data showed that glycine $(50,100,150$ p.p.m) and tryptophan (50 and $100 \mathrm{ppm}$ ) gave high significant differences compared to the control. In the first season, the highest plant height $(84,84$ or $81.89 \mathrm{~cm})$ or $(81.11 \mathrm{~cm})$ was obtained from using Glycine at either rate 50 or 100 or 150 p.p.m or tryptophan at $100 \mathrm{ppm}$ in the first season. However in the second season, the highest plant height $(84.00$ or $82.39 \mathrm{~cm})$ was obtained using Tryptophan at the level of 150 ppm or glycine $150 \mathrm{ppm}$ Those results were in agreement with El-Naggar et al., (2013). Our results were also in agreement with Abou Dahab and Abd El-Aziz, (2006) on Philodendron erubescens. They recorded that the highest plant height percentage was recorded using tryptophan compared with the control plants.

\subsubsection{Number of leaves/plant}

The data recorded in our experiments in the table (1) revealed that all the treatment gave high significantly different than the control except the treatment of tryptophan $150 \mathrm{ppm}$ and glutamine 50 $\mathrm{ppm}$ in the second season only. The largest number of leaves was noticed using glutamine at the level of $100 \mathrm{ppm}$ (11.48 and 14.17) leaf/plant in the two seasons respectively compared to the control which gave 6.56 and 6.89 leaf/plant in the two seasons respectively. Our results are in agreement with those of those found by Zahra and Morteza, (2015) on Tuberose. Our experimental results are similar to those found by (Abd El-Kader et al., 2020) on dahlia plant. Additionally, Abou Dahab and Abd El-Aziz, (2006) recorded that using tryptophan had a stimulating effect on the number of leaves/plant in philodendron. It also agrees with El-Naggar et al., (2013) on lilium.

Table 1: Average of plant height (g.), leaves number/plant and stem diameter (cm) of Philodendron selloum as affected by glycine, tryptophane and glutamine in the seasons of 2018 and 2019.

\begin{tabular}{lcccccc}
\hline \multirow{2}{*}{ Treatments } & \multicolumn{2}{c}{$\begin{array}{c}\text { Plant height } \\
\text { (cm) }\end{array}$} & \multicolumn{2}{c}{$\begin{array}{c}\text { leaves number } \\
\text { /plant }\end{array}$} & \multicolumn{2}{c}{$\begin{array}{c}\text { Stem diameter } \\
\text { (cm) }\end{array}$} \\
\cline { 2 - 7 } & $\mathbf{2 0 1 8}$ & $\mathbf{2 0 1 9}$ & $\mathbf{2 0 1 8}$ & $\mathbf{2 0 1 9}$ & $\mathbf{2 0 1 8}$ & $\mathbf{2 0 1 9}$ \\
\hline Control (0.0) & 49.33 & 50.00 & 6.56 & 6.89 & 2.52 & 2.75 \\
Glycine at 50 ppm & 84.00 & 77.17 & 10.56 & 12.11 & 3.23 & 3.42 \\
Glycine at 100 ppm & 84.00 & 79.56 & 10.78 & 13.50 & 3.39 & 3.45 \\
Glycine at 150 ppm & 81.89 & 82.39 & 10.22 & 8.28 & 3.51 & 3.60 \\
Tryptophan 50 ppm & 77.56 & 75.89 & 11.11 & 11.89 & 3.33 & 3.41 \\
Tryptophan at 100 ppm & 81.11 & 73.33 & 9.00 & 10.89 & 3.21 & 2.96 \\
Tryptophan at 150 ppm & 69.33 & 84.00 & 5.89 & 6.22 & 2.83 & 2.99 \\
Glutamine at 50 ppm & 68.89 & 72.39 & 9.44 & 6.28 & 2.62 & 2.77 \\
Glutamine at 100 ppm & 59.67 & 33.06 & 11.48 & 14.17 & 2.56 & 1.97 \\
Glutamine at 150 $\mathbf{~ p p m}$ & 66.67 & 68.11 & 8.44 & 8.99 & 2.54 & 2.66 \\
\hline L.S.D at 0.05 & $\mathbf{9 . 1 3}$ & $\mathbf{6 . 8 2}$ & $\mathbf{3 . 4 7}$ & $\mathbf{3 . 8 2}$ & $\mathbf{0 . 3 9}$ & $\mathbf{0 . 3 0}$ \\
\hline
\end{tabular}




\subsubsection{Stem diameter (cm)}

Data present in the table (1) showed that, all glycine treatment and tryptophane 50 and $100 \mathrm{ppm}$ gave high significant difference than the control. Using Glycine at the rate of $150 \mathrm{ppm}$ significantly affected the stem diameter and gave the highest stem diameter of 3.51 and $3.60 \mathrm{~cm}$, compared to the control $(2.52$ and $2.75 \mathrm{~cm})$ in the two seasons of 2018 and 2019 respectively. Thus, all amino acids used gave stem diameter significantly higher than control treatment. Those results are similar to the data found by Abou Dahab and Abd El-Aziz, (2006) on philodendron.

\subsubsection{Leaves fresh weight (g.)}

The leaves fresh weight that resulted in our experiment present in table (2) was greatly affected by using all amino acids tested in our experiment compared with the control plants. All glycine treatment and tryptophane 50 and $100 \mathrm{ppm}$ were high significantly different than the control. The highest leaves fresh weight was obtained using glycine at the level of $50 \mathrm{ppm}$ (316.84 and $296.41 \mathrm{~g}$.) in the two seasons of 2018 and 2019. Those results were in agreement with those found by Abou Dahab and Abd El-Aziz, (2006) on Philodendron eurbescens. They noted that tryptophan significantly increased fresh and dry weight leaves in both seasons. Results also agreed with the results found by (ElNaggar et al., 2013) on Lilium.

\subsubsection{Leaves dry weight (g.)}

Data in table (2) indicated that almost all treatments used gave high significant results compared with the control. The highest leaves dry weight was recorded using glycine at the level of $50 \mathrm{ppm}$ was $31.92 \mathrm{~g}$. in seasons of 2018 , however the higher leaves dry weight was $28.02 \mathrm{~g}$. in the second season 2019 using the treatment of glycine $150 \mathrm{ppm}$, compared to the control which gave the lowest leaves dry weights (10.28 and $10.77 \mathrm{~g}$.) in the two seasons, respectively. Our results agree with those found by Abou Dahab and Abd El-Aziz,( 2006) on philodendron and those found by El-Naggar et al., (2013) on tuberose.

\subsubsection{The vase life of the leaves (days)}

The amino acids glycine used in this investigation at the level of 50 and $100 \mathrm{ppm}$ and glutamine $50 \mathrm{ppm}$, highly significantly affected the vase life of the leaves cut (days) as was represented in table (2). The highest vase life recorded was 35.33 and 34.17 days in the two seasons, respectively, using the treatment of Glycine at the rate of $100 \mathrm{ppm}$ However, the control plants only recorded 6.50 and 6.00 days vase life in the two seasons, respectively. Glycine is found to be widespread amino acid applied in plant researches.

Table 2: Average of the leaves fresh weight (g.)/plant, leaves dry weight (g.)/plant and the vase life (days) of Philodendron selloum as affected by glycine, tryptophane and glutamine in the seasons of 2018 and 2019.

\begin{tabular}{lcccccc}
\hline \multirow{2}{*}{ Treatments } & \multicolumn{2}{c}{$\begin{array}{c}\text { Leaves fresh weight } \\
\text { g/plant }\end{array}$} & \multicolumn{2}{c}{$\begin{array}{c}\text { Leaves dry weight } \\
\text { g/plant }\end{array}$} & \multicolumn{2}{c}{$\begin{array}{c}\text { Vase life } \\
\text { (days) }\end{array}$} \\
\cline { 2 - 8 } & $\mathbf{2 0 1 8}$ & $\mathbf{2 0 1 9}$ & $\mathbf{2 0 1 8}$ & $\mathbf{2 0 1 9}$ & $\mathbf{2 0 1 8}$ & $\mathbf{2 0 1 9}$ \\
\hline Control (0.0) & 83.31 & 84.58 & 10.28 & 10.77 & 6.50 & 6.00 \\
Glycine at 50 ppm & 316.84 & 296.41 & 31.92 & 28.02 & 30.17 & 32.17 \\
Glycine at $\mathbf{1 0 0} \mathbf{~ p p m}$ & 287.36 & 293.68 & 28.14 & 27.34 & 35.33 & 34.17 \\
Glycine at $\mathbf{1 5 0} \mathbf{~ p p m}$ & 273.25 & 284.58 & 30.01 & 32.71 & 27.67 & 27.67 \\
Tryptophanat 50 $\mathbf{~ p p m}$ & 236.21 & 248.28 & 20.14 & 22.28 & 25.67 & 30.50 \\
Tryptophan at $\mathbf{1 0 0} \mathbf{~ p p m}$ & 221.78 & 216.99 & 14.78 & 17.01 & 23.83 & 22.67 \\
Tryptophan at $\mathbf{1 5 0} \mathbf{~ p p m}$ & 138.62 & 184.05 & 14.12 & 14.69 & 23.17 & 27.50 \\
Glutamine at 50 $\mathbf{~ p p m}$ & 145.35 & 124.42 & 13.86 & 12.63 & 31.17 & 33.17 \\
Glutamine at $\mathbf{1 0 0} \mathbf{~ p p m}$ & 98.48 & 38.44 & 11.03 & 2.32 & 28.83 & 29.33 \\
Glutamine at $\mathbf{1 5 0} \mathbf{~ p p m}$ & 123.56 & 96.10 & 10.17 & 10.80 & 28.33 & 27.83 \\
\hline L.S.D at 0.05 & $\mathbf{7 0 . 9 4}$ & $\mathbf{4 4 . 8 9}$ & $\mathbf{6 . 5 1}$ & $\mathbf{4 . 3 9}$ & $\mathbf{5 . 0 2}$ & $\mathbf{4 . 7 4}$ \\
\hline
\end{tabular}


It is especially fundamental for its nitrogen exporter for the plants that lower the carbon to nitrogen ratio, low molecular weight, and it inhibits the photo-respiration done by C3 (Zeiger, 2010). It is responsible for chlorophyll synthesis and activates vegetative growth, which is involved in the photosynthesis process. Philodendrons are considered heavy feeders (Nainwal, 2019). A regular feed with a nitrogen source will increase leaf size and produces a more significant and heal their plant. Amino acids have the greatest value in plant-feeding, with a high characteristic of accumulating dry matter Abd El-Kader et al., (2020). They were found to protect plant cells against the excess of ammonia, which led to dangerous toxicity by removing it outside the cells (Smith, 1982), while knowing that amino acids have a significant role in many organic compound biosynthesis, such as alkaloids, pigments, enzymes, vitamins, and coenzymes (Abd El-Kader et al., 2020). Amino acids as growth stimulators were used to have better growth in ornamental plants. The previous results in our investigation were in agreement with those found by Abd El-Aal et al., (2010) in squash plants. They found that using $500 \mathrm{ppm}$ of amino acid mixture resulted in a vigor plant growth compared to the control plants. Protein assimilation and dry matter accumulation always led to healthier growth than better fresh and dry weights; thus, a better vase life. Many researchers noted that the stimulatory effect of amino acids might be due to the vital essential impact of these organic nitrogen sources on the growth of all plant cells. Those amino acids are a source of carbon and energy for plant growth by breaking into ammonia and organic cells when carbohydrates become deficient. Moreover, amino acid, which is converted into some growth regulators, may result from its great success in plant growth. Our results were in agreement with those found by Talaat et al., (2005). They recorded that using Tryptophan on Catharanthus roseus L. led to an increase in periwinkle growth due to its conversion into indole acetic acid (I.A.A.).

\subsection{Chemical Analysis:}

\subsubsection{Chlorophyll A ( $\mathrm{mg} / 100 \mathrm{~g}$ fresh weight)}

The data in Table (3) showed that all amino acids used in our experiment led to high significant chlorophyll high results compared to the control plants treatment. The highest chlorophyll A obtained when treating with glycine $(150 \mathrm{ppm})$ was 197.99 and $185.78 \mathrm{mg} / 100$ g.f.w. in the two seasons, respectively, compared with the control (78.75 and $78.37 \mathrm{mg} . / 100$ g.f.w.), respectively. Those results agree with what was found by Zahra and Morteza,(2015).

Results agree with the findings of El-Naggar et al., (2013) on chlorophyll A, B on Lilium

\subsubsection{Chlorophyll B ( $\mathrm{mg} / 100 \mathrm{~g}$ fresh weight)}

The data represented in table (3) indicated that the highest chlorophyll B content recorded was 70.22 and $63.20 \mathrm{mg} / 100$ g.f.w. using the treatment of the Glycine at the rate of $150 \mathrm{ppm}$ in the two seasons compared with the control plants ( 34.94 and $33.28 \mathrm{mg} / 100 \mathrm{~g}$.f.w.) of chlorophyll B in the two seasons respectively. Those results agree with all the findings of Mahdi and Saeed, (2019); Radkowski and Radkowska, (2018) and Abou Dahab and Abd El-Aziz,(2006). In addition, Radkowski and Radkowska, (2018) had the same trend of results on Phleum patense, they added that leaf green SPAD was higher in plots receiving higher amino acid doses. Our results disagree with the findings by Abou Dahab and Abd El-Aziz,(2006) on Philodendron eurbescens. Their treatments did not significantly affect the chlorophyll A and B in the first season and a significant one in the second season. The results found in our experiment were in agreement with those found by Mahdi and Saeed, (2019) on Gerbera jamesonii.

\subsubsection{Total carotenoids $(\mathrm{mg} / 100 \mathrm{~g}$ fresh weight)}

The data presented in table (3) showed that, all the treatments in this experiment were significantly different than the control. Increasing the concentration of glycine used in this investigation caused an increase in the total carotenoids extracted from the leaves. It resulted in the highest level of carotenoids ( 35.80 and $33.80 \mathrm{mg} / 100$ g.f.w.) at the two seasons, respectively compared with the control plants treatment (19.37 and $18.36 \mathrm{mg} / 100$ g.f.w.). Amino acids have a superior value in the plant feeding for earning and gaining big yields and maximum dry matter (El-Naggar, et al., 2013). The promotive effect of the amino acids used in our investigation, may be due to its role in the chlorophyll biosynthesis which in turn affected carbohydrates content. Since philodendron is a foliage herbaceous ornamental plant; thus accumulation in dry matter and a good chlorophyll assimilation which can lead to healthier pants with longer cut foliage vase life. 


\subsubsection{Total carbohydrate (\%)}

Data presented in table (3) showed that, all the treatments in this experiment were significantly different than the control. The highest total carbohydrate was 11.35 and $11.87 \%$ using glycine $100 \mathrm{ppm}$ treatment compared with the control which resulted in 8.95 and $8.35 \%$. Those results were in agreement with results found by El-Naggar, et al., (2013) in leaves of lilium. They stated that the promotive effect of the amino acids on carbohydrates content may be due to their important role on the chlorophyll biosynthesis which in turn affected carbohydrates content. Our results agree with those found by Mahdi and Saeed, (2019) in leaves of Gerbera jamesonii L.

Table 3: Average of chlorophyll A, B, carotenoids content (mg/100g.f.w.) and total carbohydrates (\%) in leaves of Philodendron selloum as affected by glycine, tryptophane and glutamine in the seasons of 2018 and 2019.

\begin{tabular}{lcccccccc}
\hline & \multicolumn{2}{c}{$\begin{array}{c}\text { Chlorophyll A } \\
\text { (mg/100g.f.w.) }\end{array}$} & \multicolumn{2}{c}{$\begin{array}{c}\text { Chlorophyll B } \\
\text { (mg/100g.f.w.) }\end{array}$} & \multicolumn{2}{c}{$\begin{array}{c}\text { Carotenoids } \\
\text { (mg/100g.f.w.) }\end{array}$} & \multicolumn{2}{c}{$\begin{array}{c}\text { Total } \\
\text { carbohydrate } \\
\text { (\%) }\end{array}$} \\
\cline { 2 - 9 } & $\mathbf{2 0 1 8}$ & $\mathbf{2 0 1 9}$ & $\mathbf{2 0 1 8}$ & $\mathbf{2 0 1 9}$ & $\mathbf{2 0 1 8}$ & $\mathbf{2 0 1 9}$ & $\mathbf{2 0 1 8}$ & $\mathbf{2 0 1 9}$ \\
\hline Control (0.0) & 78.75 & 78.37 & 34.94 & 33.28 & 19.37 & 18.36 & 8.95 & 8.35 \\
Glycine at 50 ppm & 150.46 & 179.19 & 47.41 & 58.80 & 26.39 & 31.90 & 10.01 & 10.41 \\
Glycine at 100 ppm & 178.99 & 167.06 & 60.36 & 48.09 & 31.43 & 30.13 & 11.35 & 11.87 \\
Glycine at 150 ppm & 197.99 & 185.78 & 70.22 & 63.20 & 35.80 & 33.80 & 10.93 & 9.91 \\
Tryptophan at 50 ppm & 159.60 & 164.57 & 53.59 & 55.04 & 30.08 & 30.84 & 9.47 & 9.70 \\
Tryptophan at $\mathbf{1 0 0} \mathbf{~ p p m}$ & 188.45 & 165.86 & 67.13 & 57.40 & 33.77 & 29.66 & 9.07 & 9.25 \\
Tryptophan at $\mathbf{1 5 0} \mathbf{~ p p m}$ & 176.68 & 167.03 & 62.84 & 57.61 & 33.63 & 32.60 & 10.64 & 10.44 \\
Glutamine at 50 ppm & 174.03 & 172.87 & 61.82 & 61.60 & 31.00 & 30.10 & 10.09 & 10.46 \\
Glutamine at 100 $\mathbf{~ p p m}$ & 127.91 & 148.57 & 43.50 & 49.70 & 23.63 & 26.59 & 10.02 & 9.76 \\
Glutamine at 150 $\mathbf{~ p p m}$ & 123.00 & 157.93 & 50.79 & 57.25 & 21.83 & 29.17 & 8.77 & 8.89 \\
\hline L.S.D at 0.05 & $\mathbf{4 6 . 1 6}$ & $\mathbf{4 1 . 7 8}$ & $\mathbf{2 2 . 0 2}$ & $\mathbf{1 4 . 4 0}$ & $\mathbf{6 . 3 1}$ & $\mathbf{6 . 5 5}$ & $\mathbf{1 . 1 1}$ & $\mathbf{1 . 0 3}$ \\
\hline
\end{tabular}

\section{Conclusion}

From the previous data in our experiments it could be concluded that, using five foliar applications of glycine at $50 \mathrm{ppm}$ with one month intervals, resulted in a significant increase in Philodendron selloum cv. "Rayo" plant height, leaves fresh weights. Glycine foliar spray at the rate of $100 \mathrm{ppm}$ resulted in the best foliar cuts vase life and the highest total carbohydrates in leaves. Finally, a foliar spray of glycine at the level of $150 \mathrm{ppm}$ gave the highest chlorophyll A,B, total carotenoids and stem diameter in the two seasons compared with the control.

It is also recommended to use glycine at $50 \mathrm{ppm}$, five foliar spray with one month intervals on Philodendron selloum cv."Rayo," among other amino acids used in our investigation, for its good response in most of the parameters used in our experiment.

\section{Acknowledgements}

The author is very grateful to my colleague associate professor Dr. Naglaa Moustafa for her collaboration in this investigation during statistical analysis. The author is very grateful for her two daughters Nouran, for her collaboration during data entry and computer transcribe and Linah, for her efforts and cooperation in collecting data. 


\section{References}

Abd El-Aal, S.F., A.M. Shaheen, A.A. Ahmed and R.A. Mahmoud, 2010. Effect of foliar application of urea and amino acids mixtures as antioxidants on growth, yield, and characteristics of squash. Res. J. Agri. And Biol. Sci., 6(5): 583-588.

Abd El-Aziz, G.N. and K.L. Balbaa, 2007. Influence of tyrosine and zinc on growth flowering and chemical constituents of Salvia farinacea. Egypt. J. Appl. Sci., 3(11): 1479-1489.

Abd El-Aziz, N.G., M.H. Mahgoub, and A.A.M. Mazher, 2009. Physiological effect of phenylamine and tryptophan on the growth and chemical constituents of Antirrhinum majus plants. Ozean J. Appl. Sci., 2: 399-407.

Abd El-Aziz, N.G., A.M. Mazher, and M.M. Farahat, 2010. Response of vegetative growth and chemical constituents of Thuja orientalis L. plant to foliar applications of different amino acids at Nubaria. J. of Amer. Sci., 6(3), 295-300.

Abd El-Kader, H.H., M.M. Kasem, T.T.E. Younis, and A.E.A. Gad, 2020. Impact of some amino acids on vegetative parameters, flowering and chemical constituents of dahlia cut flowers. J. of Plant Production, Mansoura Univ., 11(4): 333-339.

Abou Dahab, T.A.M and Abd El-Aziz G. Nahed, 2006. Physiological effect of diphenylamine and tryptophan on the growth and chemical constituents of Philodendron erubescens plants. World $\mathrm{J}$. of Agric. Sci., 2(1): 75-81.

Bohmig, F., 1958. Gätnerische Kulturpraxis. MitZahlreichen Abb. Neumann Verlag, Radebeul, 236. Breś W., Golcz A., Komosa A., Kozik E., Tysiński W. 2008. Nawozenieroślinogrodniczych (Fertilization of horticultural plants). Wyd. UPwPoznaniu, Poznań 2008, 5-189.

Chellamuthu, V.R., E. Ermilova, T. Lapina, J. Lüddecke, E. Minaeva, C. Herrmann, M.D. Hartmann, and K. Forchhammer, 2014. A widespread glutamine-sensing mechanism in the plant kingdom. Cell, 159 (5): 1188-1199.

Chen, J., R.J. Henny, D.B. McConnell, and R.D. Caldwell, 2003. Gibberellic acid affects growth and flowering of philodendron, Black cardinal; Plant Growth Regulation, 41: 1-6.

Eid, A.R., S.L. Taha, and M.M.S. Ibrahim, 2010. Physiological properties studies on seential oil of Jasminum grandiflorum L. as affected by some vitamins. Ozean J. Appl. Sci., 3(1): 87-96.

El-Naggar, A.A.M., A.I. Adam, and F.E. El-Tony, 2013. Response of Longiflorum X Asiatic hybrid lilium plants to foliar spray with some amino acids. Alex. J. Agric. Res., 58 (3): 197-208.

Gross, J.A., 1973. Amino Acids Synthesis and Metabolism Physiology of Plants and their Cell. Pergamon Press INC, New York, Toronto, Oxford, Sydney, Braunschweig.

Hedge, J. E, and B.T. Hofreider, 1962. In: Carbohydrate Chemistry, 17 (Eds Whistler R.L. and Be Miller, J. N.), Academic Press, New York.

Mahdi, S.A. and A.A.J. Saeed 2019. Effect of tryptophan and phenylalanine on some biochemical components and floral traits of (Gerbera jamesonii L.) cv. 'Great smoky mountains.' Plant Archives, 9(1): 1051-1056.

Mazher, A.M.A., A.A. Yassen, and M.S. Zaghloul, 2007. Influence of foliar application of potassium on growth and chemical composition of Buhinia variegate seedlings under different irrigation intervals. World J. Agric. Sci., 3(1): 23-31.

Moran, W.B., 1982. Formula for determination of chlorophyllous pigments with N-N-dimethyl formamide. Plant Physiol., 69: 1376-1381.

Nainwal, P., 2019. Review of Philodendron species plant seeking for validation of its therapeutic approaches. J. Pharm. Sci. and Res., 11(5): 2003-2006.

Radkowski, A. and I. Radkowska, 2018. Influence of foliar fertilization with amino acids preparations on morphological traits and seed yield of timothy. Plant Soil Environ., 64(5): 209-213.

Smith, T.A., 1982. The function and metabolism of polyamines in higher plants. In Wareing P.E. (Ed.), Plant Growth Substances. Academic Press, Ames, Iowa, U.S.A.

Snedecor, G.W. and W. Cochran, 1989. Statistical Methods, Eighth Edition, Iowa State University Press.

Talaat, I.M., 2005. Physiological effect of salicylic acid and tryptophan on Pelargonium graveolens. Egypt. J. Appl. Sci., 20: 751-760

Talaat, I.M., M. Karima, and K.M. Gamal-El-Din, 2005. Physiological effect of putrescine and heat hardening on Nigella sativa L. plants Intl. J. Agric. Biol., 358-362. 
Talaat, I.M. and A.A. Youssef, 2002. The role of amino acids lysine and ornithine in growth and chemical constituents of basil plants. Egypt, J. Appl. Sci., 17:83-95.

Zahra, A. and K. Morteza 2015. Efficacy of spraying a mixture of amino acids on the physiological and morphological characteristics of tuberose (Polianthes tuberosa L.) International J. of Horticultural Sci. and Technology, 2(2): 199-204.

Zeiger, T., 2010. Plant Physiology. $4^{\text {th }}$ ed. Sinaure Associates. 